\title{
The Effect of Islamic Work Ethics on Job Satisfaction, Organizational Commitment, Turnover Intention, and Innovation Capability
}

\author{
Dita Oriana ${ }^{1}$,Evony Silvino Violita ${ }^{2}$ \\ \{dita.oriana@gmail.com ${ }^{1}$, evony.silvino@gmail.com ${ }^{2}$ \} \\ Universitas Indonesia, Depok, Indonesia ${ }^{1}$ \\ Corresponding Author: Department of Accounting, Universitas Indonesia, Depok, Indonesia ${ }^{2}$
}

\begin{abstract}
This study aims to examine the effect of Islamic Work Ethics on job satisfaction, organizational commitment, turnover intention and innovation capability of employees. Data obtained from the questionnaires distributed to 172 employees who worked in a leading Islamic bank in Indonesia and interviewed several employees to strengthen the analysis. Data was performed by descriptive analysis and partial least squares. The results indicates that Islamic Work Ethics significantly shape job satisfaction, organizational commitment, turnover intention, and innovation capability. This research can be useful for Islamic Banks to improve the management policy to Islamic Work Ethics in their organization culture.
\end{abstract}

Keywords: Islamic Work Ethics (IWE), Job Satisfaction, Organiational Commitment, Turnover Intention, Innovation Capability.

\section{Introduction}

Organization has various roles that are made in order that the organization has a structured system. Employees have an important role to make the organization successfully achieve its goals. In carrying out their work, the employees should follow regulations that have been made by the organization beside following existing work ethics. Job satisfaction, organizational commitment, and turnover intention are important things to be considered in human resource management. Other important thing is to create ideas or innovations that is useful to improve the organization. In the western business world, it is known as Protestant Work Ethics (PWE). PWE develops and is advocated by Max Weber [1]. Regardless the impact of Protestantism and PWE on economic development in the West (Weber, 1958), the application of models based on these elements may be limited in non-western societies especially in eastern countries such as Indonesia whose people are Muslims. Islam has a concept and practice about ethics derived from the Qur'an and Sunnah. In a manner that is similar with Weberian Protestantism, Islam provides the basic ideology especially in the work ethic that certainly impacts on development, or in this paper called Islamic Work Ethics (IWE).

Both PWE and IWE have primary focus on hard work, dedication, commitment, creativity, avoidance of accumulated wealth by unethical means, and workplace cooperation. However, different from PWE, IWE emphasizes more at intentions where PWE emphisizes more at result [2], although it does not mean that IWE ignore the results. IWE is derived from the Qur'an 
(Muslim holy book) and Sunnah (words and practices) of the Prophet Muhammad [1]. Understanding business ethics from Islamic perspective becomes important for several reasons. First, Islam is the second largest religion in the world (after Christianity) which is $22.5 \%$ of the world population. The Muslim population worldwide continues to grow. The Muslim population grew more than 1.5 times faster than the general population [3]. Especially in Indonesia, the majority population of Indonesians are Muslim. Therefore, IWE in Indonesian organizations has an important role. Data show that the highest number of Indonesian population are Muslim which is 207 Million compared to the number of other relation in 2010.

Table 1 Population Data of Indonesia by Religion in 2010

\begin{tabular}{ccc}
\hline Religion & Total & Percentage \\
\hline Islam & 207.176 .172 & $87.7 \%$ \\
Kristen & 16.528 .513 & $7.0 \%$ \\
Katolik & 6.907 .873 & $2.9 \%$ \\
Hindu & 4.012 .116 & $1.7 \%$ \\
Budha & 1.703 .254 & $0.7 \%$ \\
\hline
\end{tabular}

Sources: Statistics Center Bureau Indonesia

In the banking industry, the issue of work ethics is also important and needs to be considered. Indonesia applied dual banking system where both conventional and sharia banking exist. As a shariah-compliant banking that follows Islamic law, the ethics of work should follow the Islamic Work Ethic (IWE). The ethos of Islamic work will affect how the employees act and makes a decision.

This researchaims to examine whether Islamic banking apply Islamic Work Ethics in working practices conducted by its employees and test the influence of Islamic Work Ethics on on job satisfaction, organizational commitment, turn over intention and organizational innovation ability. This research takes place in one of the largest Islamic banks in Indonesia. This bank has been operating in Indonesia for almost 19 years. The surveyed bank has 737 service offices spread across Indonesia, with access more than 196,000.

\section{Literature Review}

\subsection{Islamic Work Ethics}

IWE is analogous to the concept of Islamic Shari'ah that emphasizes cooperation in work, discussion is seen as a way of overcoming obstacles, avoiding mistakes to meet one's needs, and building equilibrium in one's individual and social life [4]. This study used a processed question derived from measurements made by Ali (1992) and Abuznaid (2009) to measure the IWE variables [5], [6]. The study has 18 questions to measure IWE (questionaires is attached).

\subsection{Job satisfaction}

Job satisfaction is the employees' perceptions of how well their work is considered important [7]. Job satisfaction can also be understood as a perseption of individual of their work 
[8]. That means an employee who has a high level of job satisfaction will survive and have a positive feel to the job and vice versa. Usually, job satisfaction is a person's evaluation of the overall quality of his current job. To measure Job Satisfaction variables, researchers used measurements made by Dubinsky \& Harley (1986) [9]. The study has 3 questions to measure job satisfaction (questionaires is attached).

\subsection{Organizational Commitment}

Organizational commitment is an inherent psychological state of an employee for an organization, thus reducing the incidence to get out of the company. Organizational commitment is a psychological bond to employees characterized by a strong belief and acceptance of the organization's goals and values, the willingness to work towards the achievement of the organization's interests and the desire to preserve the position of an organization member. This research measures the Organizational Commitment variable using Organizational Commitment Questioners (OCQ) adapted by Bozeman \& Perrewe (2001) represented by 3 questions (questionaires is attached) [10].

\subsection{Turnover Intention}

Turnover is a process by which employees leave the organization and the job position [11]. To measure the Intend Intence variables, this research used questions from Hom \& Griffeth (1991) and Luna-Arocas, R., and Camps (2008) [12], [13]. The study has 3 questions to measure the Exit Intention.

\subsection{Innovation Capability}

The ability of innovation is understood as the level of confidence that public sector organizations generate new ideas to improve the delivery of public services or create new products [14]. The performance of public sector organizations is the result of an individual's collective action based on the value of the individual. The direction of organizational innovation becomes crucial in ensuring sustainability and improving overall customer and employee satisfaction. To measure the variable Innovation Capability, this research used measurements made by Lee \& Choi (2003) [14]. The study has 5 questions to measure innovation capability.

\section{Research Methodology}

This study aims to see the influence of Islamic Work Ethics variables on Job Satisfaction, Organizational Commitment, Turnover Intention, and Innovation Capability. Type of research in this study using the type of quantitative research. Researchers used single cross-sectional design method in collecting information related to the research that will be conducted by using survey to get information related to the respondent that is once in one period in the sample [15]. Objects in this study are the employees who work in the sample bank (let us name it Bank Arafaa fake name). The method used in this research is Partial Least Square SEM and conducting interviews to strengthen the analysis. This research framework adopt Rokhman (2010) that used Baitul Maal wat-Tamwil at Central Java region by taking a sample of 49 respondents and also research models conducted by Kumar \& Rose (2008) [4], [16]. Research model in this research as follows: 


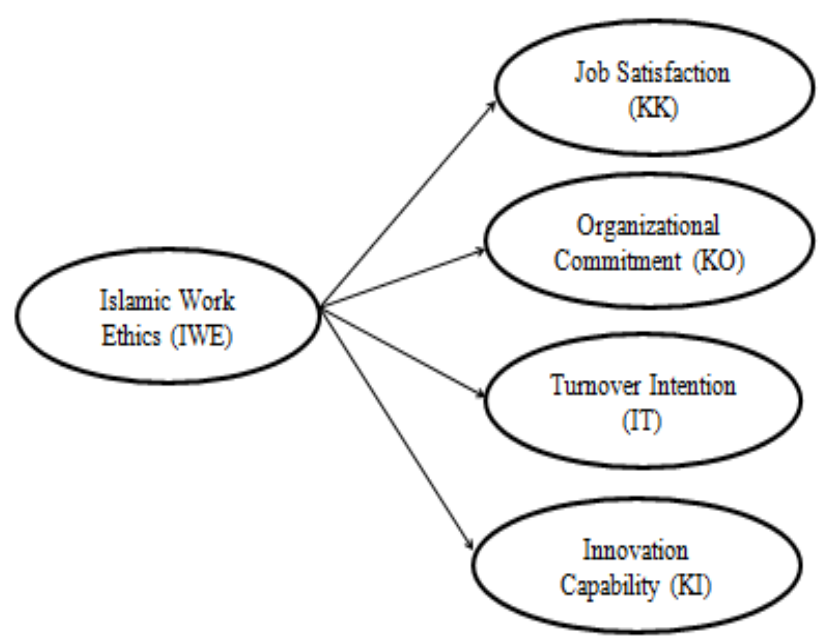

Fig. 1. Research Framework

Islamic work ethics (IWE) has positive values as to give a positive influence on employee job satisfaction. Positive values are reflected in Islamic values such as the importance of dedication, high integrity of work, honest nature, and provide the best ability for the company. In Islam itself also emphasizes the importance of work, so that Muslims should give their best ability in working and increasing job satisfaction. Therefore, the hypotheses is as follows:

\section{H1: Islamic Work Ethics (IWE) positively effect on Job Satisfaction.}

Islamic work ethics (IWE) makes working atmosphere more comfortable for its workers, because in IWE it is not only concerned with mundane affairs but also of religious affairs. Carrying out worldly affairs with religious provisions. It brings more comfortable atmosphere to support organizational commitment. Putti et al. (1989) [21] finds that work ethics positively influence organizational commitment. Here is the hypotheses:

\section{H2: Islamic Work Ethics (IWE) positively affects Organizational Commitment.}

As has been explained, by applying Islamic work ethics (IWE) then the turnover intention employees of the organization will be reduced. Because IWE basically makes the work curve comfortable so that the possibility to get out of the company will be reduced because of a sense of comfort to the work environment, then the hypotheses is as follows:

H3: Islamic Work Ethics (IWE) negatively affects Turnover Intention.

By implementing Islamic Work Ethics (IWE), the innovation of the organization will increase. Islam teach people to study. Having knowledge creates a person's mindset and creates a new idea that can make innovation and innovation positive. So:

H4: Islamic Work Ethics (IWE) positively effect on Innovation Capability. 
The model of the research is as follows:

$$
\mathrm{Yn}=\mathrm{f}(\mathrm{IWE})
$$

Variable $\mathrm{Yn}$ is a dependent variable, where $\mathrm{Y} 1$ is the variable of job satisfaction, $\mathrm{Y} 2$ is the organizational commitment variable, Y3 is the outgoing intention variable, Y4 is the variable of innovation ability. The result of the variable explains that variable $\mathrm{Y}$ is a function of IWE (Islamic Work Ethics), dependence on changes in variable $\mathrm{X}$. The research variable is a symbol of an event, action, characteristics, characteristics or properties that can be measured and assigned value [17]. Here are the variables contained in this study, namely:

\section{Independent Variable (Independent Variable)}

The independent variable is a manipulated variable or alternative and that affects the measurement of the dependent variable [17]. In this research which is independent variable is Islamic Work Ethics (IWE)

\section{Dependent Variable}

Dependent variables are variables that are measured, predicted or monitored, and are expected to be influenced by independent variables [17]. In this study which is the dependent variable of Job Satisfaction, Organizational Commitment, Turnover Intention, and Innovation Capability.

The population in this study are employees who work in the division of Bank Syariah Arafah (a fake name of a leading Islamic bank in Indonesia). The number of questionnaires distributed as many as 200 questionnaires, where the number of collected 181 questionnaires using the likert scale 1 to 6 . From 181 questionnaires, there are 9 questionnaires whose fill is not filled completely. Therefore, the number of questionnaires that can be processed as much as 172 respondents. The technique of sampling from this research using Non-probability Sampling method is sampling technique which does not give equal opportunity or opportunity for every element or member of population to be chosen as sample. According to Hair et al (2006) how to determine the number of samples is an indicator at times 5, or $32 \times 5=160$ [18].

Researchers conducted pretest first to 30 employees of Bank Syariah Arafah. This pre-test to determine the validity and reliability test in this research questionnaire and test the questionnaire in this research. A dimension of a variable whose results are reliable, if Cronbach's Alpha results in the dimensions of the variable $\geq 0.6$. A dimension of a variable can be said to be valid if it has been tested for its validity by looking at the Kaiser-Meyer-Olkin (KMO) value of $\geq 0.5$ and Bartlett's Test of Sphericity to see the significance of its value should be below 0.05 [15]. From the results of reliability test using SPSS 24, states that the variables in this study has been reliably tested, because the value of Cronbach's Alpha in this study $\geq 0.6$. In the validity test, for the variables of Islamic work ethics, job satisfaction, organizational commitment, turnover intention and innovation capability are tested for its validity because the KMO value of $\geq 0.5$ and significance value at Bartlett's test is below 0.05 which means the value is significant. Then after doing pretest the researchers do the main test with a total of 172 respondents. 


\section{Results}

Table 2. Outer Model Test

\begin{tabular}{|c|c|c|c|c|c|}
\hline Variabel & AVE & $\begin{array}{c}\text { Cronbach } \\
\text { Alpha }\end{array}$ & $\begin{array}{l}\text { Composite } \\
\text { Reliability }\end{array}$ & $\begin{array}{c}\text { Cross } \\
\text { Loading } \\
\text { (value of } \\
\text { dimension) }\end{array}$ & P Values \\
\hline IWE & 0.358 & 0.893 & 0.908 & $\begin{array}{c}>\text { IWE } \\
\text { variable }\end{array}$ & $\begin{array}{l}0.000 \text { Every } \\
\text { Dimensions }\end{array}$ \\
\hline IT & 0.703 & 0.794 & 0.876 & $\begin{array}{c}>\text { IT } \\
\text { variable }\end{array}$ & $\begin{array}{l}0.000 \text { Every } \\
\text { Dimensions }\end{array}$ \\
\hline $\mathrm{KI}$ & 0.538 & 0.787 & 0.852 & $\begin{array}{c}>\mathrm{KI} \\
\text { variable }\end{array}$ & $\begin{array}{l}0.000 \text { Every } \\
\text { Dimensions }\end{array}$ \\
\hline KK & 0.655 & 0.736 & 0.851 & $\begin{array}{c}>\mathrm{KK} \\
\text { variable }\end{array}$ & $\begin{array}{l}0.000 \text { Every } \\
\text { Dimensions }\end{array}$ \\
\hline $\mathrm{KO}$ & 0.609 & 0.706 & 0.822 & $\begin{array}{c}>\mathrm{KO} \\
\text { variable }\end{array}$ & $\begin{array}{l}0.000 \text { Every } \\
\text { Dimensions }\end{array}$ \\
\hline
\end{tabular}

In the research model, researchers include all indicators on each variable and the table above is the result of processing. In the IWE, $\mathrm{KK}, \mathrm{KO}$, IT and $\mathrm{KI}$ variables there is no problem because the variables are feasible. We can see from the AVE values greater than 0.5 and below 0.4 , the Cronbach Alpha value is greater than 0.6, the composite reliability value greater than 0.7 Hair et al, 2010), the value of cross loading of each variable is greater to the variable itself, and $p$-values indicating that each indicator variable is $<0.05$ where the significance level is $95 \%$ [18], [19].

In the IWE variable the value of AVE 0.358 where according to Bagozzi (1988) goes into the AVE criteria below 0.4 [19]. Furthermore, the theory that accepts AVE values below 0.5 is also according to Fornell \& Larcker (1981) where an AVE value below 0.5 is acceptable as long as the composite reliability value of the variable is $\geq 0.6$ [20]. Then the Cronbach's alpha value of the IWE variable is 0.893 which means the value is greater than 0.6 . The composite reliability value of the IWE variable is 0.908 which means that the value is greater than 0.7 . Then cross loading of the IWE variable indicates that the IWE variable value is greater in the IWE variable itself than in other variables. Then to test the significance of the outer model on the IWE variable, and $p$-values indicating that each indicator variable is $<0.05$ where the significance level is $99 \%$. While for variables $\mathrm{KK}, \mathrm{KO}, \mathrm{IT}$, and $\mathrm{KI}$ is reliable and valid in accordance with the provisions.

Table 3. Goodness of Fit's Test

\begin{tabular}{ccc}
\hline Variable & $\boldsymbol{R}^{\mathbf{2}}$ & Communality \\
\hline KK & 0.176 & 0.655 \\
KO & 0.082 & 0.609 \\
IT & 0.040 & 0.703 \\
KI & 0.140 & 0.538 \\
\hline
\end{tabular}




\begin{tabular}{lcc}
\hline \multicolumn{1}{c}{ average } & 0.110 & 0.626 \\
\hline Gof: $\sqrt{0.110 \times 0.626}=0.262$ & \\
KK: Job Satisfaction, KO: Organizational Commitment, IT: Turnover Intention, KI: \\
Innovation Capability
\end{tabular}

\section{Source: Researcher's Results Using Smart PLS 3.0}

The result of Goodness of Fit on the research model has a value of 0.262 . Goodness of Fit to know the research model is appropriate / feasible. Small GoF value is 0.1 , GoF value of medium is 0.25 and big GoF value is 0.38 . GoF values in this research model fall into the medium category. The value of the medium is a value that is in the middle-level position, with a range of values from 0.25 to 0.37 . After calculating the value of Goodness of Fit, then we do hypothesis test and significance test.

Table 4. Hypothesis Test

\begin{tabular}{cccc}
\hline Variable & $\begin{array}{c}\text { Expectation } \\
\text { related to }\end{array}$ & Original Sample & P Values \\
\hline IWE $\rightarrow$ IT & - & -0.199 & $0.007^{* * *}$ \\
$\mathbf{I W E} \rightarrow \mathbf{K I}$ & + & 0.374 & $0.000^{* * *}$ \\
$\mathbf{I W E} \rightarrow \mathbf{K K}$ & + & 0.420 & $0.000^{* * *}$ \\
$\mathbf{I W E} \rightarrow \mathbf{K O}$ & + & 0.286 & $0.000^{* * *}$ \\
\hline$* * *$ Significance Level 99\% & \\
$* *$ Significance Level 95\% & \\
\hline \multicolumn{2}{c}{ Source: Researcher's Results Using Smart PLS 3.0 }
\end{tabular}

The table above explains that the IWE variable to KK has original sample value of 0.420 indicates that the value is positive. P-values value is 0,000 where the value $<0.01$ of the result states that the IWE variable to KK is significant. So, the hypothesis H1 which states that Islamic Work Ethics has a positive effect on Job Satisfaction is accepted.

IWE variable to $\mathrm{KO}$ has original value sample of 0.286 indicates that the value is positive. the value of P-values is 0.00 where the value $<0.01$ of the result states that the IWE variable to the $\mathrm{KO}$ is significant. So, the hypothesis $\mathrm{H} 2$ which states that Islamic Work Ethics has a positive effect on Organizational Commitment is accepted.

IWE variable to IT has original sample value of -0.199 indicates that the value is negative. The value of P-values is 0.007 where the value $<0.01$ indicates that the IWE variable to IT is significant. Hence, the hypothesis $\mathrm{H} 3$ which states that Islamic Work Ethics negatively affect the Turnover Intention is accepted.IWE variable to KI has original value sample of 0.374 indicates that the value is positive. the value of P-values is 0.00 where the value $<0.01$ indicates that the IWE variable to KI is significant. The hypothesis H4 which states that Islamic Work Ethics have a positive effect on Innovation Capability accepted.

\section{Discussion}

The result finds that IWE affect job satisfaction, turnover intention, organizational commitment, and innovation capability. IWE is found to have positive effects on job satisfaction, organizational commitment and innovation capability, while negative effect on turnover intention. Each indicator on each variable is feasible and in accordance with the criteria 
so that no indications are deleted in this study. Islamic Work Ethics variable affects Job Satisfaction variable of $17.6 \%$ where the value is the highest value compared to other variables. Then the Islamic Work Ethics variable affects the Organizational Commitment variable by $8.2 \%$, affect the Turnover Intention variable by $4 \%$ and affect the innovation capability by $14 \%$. These results explain that job satisfaction and innovation capability can be increased by using Islamic work ethics because it has a considerable influence. Meanwhile, IWE has a moderate effect on the turnover intention and organizational commitment.

The interview describe that to some employees apply IWE in carrying out their work. For instance is that they like cultivating diligent, persistent, always remembering God in work, avoiding fraud and corruption, trying to become better human beings every day, especially in working, keeping in touch with God and man (among workers) and other ethical values of Islamic work. Basicaly, the sample Bank has applied the ethical principles of Islamic work to its employees in a working culture called Shared Value Ethics where there are 5 values contained are Excellence, Team Work, Humanity, Integrity, and Customer Focus. For example, in terms of Integrity the employees must be obedient, trustworthy, honest, and other positive things. Shared Value Ethics itself already includes Islamic syariat in it. Another example is that the sample bank has applied the ethics of Islamic work in the work environment that is reflected from religious activities carried out by the company. Every morning before starting work, every employee do morning prayer together and every Friday held tadarus al-qur'an together.

The results of the study accepted H1 that IWE has a positive effect on Job Satisfaction, which means that the ethics of Islamic work has an influence and role to job satisfaction. The interviews conducted confirm that employees are satisfied with the benefits and compensation provided by the company, in addition to the employees are also satisfied with the competence of leaders in this company. On the other hand, the employees feel not satisfied with the results of work because they think if someone is satisfied with the results of his work then the person will not try to get better. The employees at Bank Syariah Arafah strive to deliver their best performance results. IWE is reflected in the nature of the leaders and employees of the Bank Arafa. They are satisfied with their salary even when compared to other smaller companies. Instead, they are looking for blessings from the work they do. Employees stated that the factors that affect their satisfaction working in the company is the work culture, work environment in the Bank Arafa convenient because following the principles of sharia, fellow employees and superiors also have a good attitude such as mutual help-help. In addition, the more technical part of the job to be executed affects the employee's job satisfaction such as preparation for doing the work and the tools for the job such as available office facilities are fulfilled. Although in terms of technology, computer equipment in Bank Syariah Arafah is still lagging behind and needs to be improved in terms of facilities in the field of technology. The employees here also stated that they like the kind of work they do in Bank Syariah Arafah.

The next hypothesis proves that the ethics of Islamic work have a positive effect on organizational commitment. From this result stated that the employees of Bank Syariah Arafah have high organizational commitment to work in Syariah Bank Arafah. From the results of organizational commitment can reflect the subsequent hypothesis that proves that Islamic Work Ethics negatively affect the turnover intention employees at Bank Syariah Arafah. From the interviews explained that employees like and want to stay in Syariah Bank Arafah until retirement. But there are also employees who claim that have a target to stop at a certain age because they want to reach a dream that is difficult to reach in this company. In addition to the female employees here also states that there is a possibility to get out of the company because of family factor that is to carry out its duties as a housewife so that must stop from work. But many of them have a high commitment to stay in this company. Their reason for staying in this company is because they are comfortable with work culture, shariah based work environment, because some employees previously worked in non-sharia companies and stated that there are 
significant differences between sharia and non-sharia companies. Therefore, they survived to work in Bank Syariah Arafah. Islamic work ethics embedded in employees makes them committed to staying in this company.

The last hypothesis proves that the ethics of Islamic work have a positive effect on the innovation Capability. This proves that the importance of innovation capability possessed by employees to make companies to grow and survive in the era of globalization. Bank Arafa also demands employees to make an innovation, the container of employees to deliver innovation is reflected in an annual competition conducted by Bank Syariah Arafah. The ethics of Islamic work are very important and affect the ability of innovation made by the employees. In the interview, some employees stated that the ethics of Islamic work play a role to filter the innovations made so that the innovation has a positive nature. People who have a high ethical Islamic work will surely adhere to and implement the principles of sharia, so that innovations are made directed to the positive side that will be useful and contain maqashid al-shariah. The age of the employees at Bank Syariah Arafah is average at 31-40 years old, at that age of course someone already know their best choice in work. At that age is a mature age to do a good work productivity, where the employees already have previous work experience to produce good output. In terms of generating innovation is also very good, where the employees have many innovative ideas that come from their reason and also the existing reality to improve a system to be better.

\section{Conclusion}

The results of research that states that accept the first hypotheses that IWE has a positive effect on job satisfaction. The findings are similar to the results of research conducted by Rokhman (2010) [16]. In the second hypothesis states that Islamic work ethics has a positive effect on organizational commitment, the results of this research receive H2. While the difference in hypothesis of this research is the influence of Islamic work ethics to turnover intention, which in research conducted by Rokhman (2010) IWE negatively affect the turnover intention but not significant, whereas in this research IWE negatively turnover intention and significance [16]. Differences can be seen in terms of significance. The results of this study also received results from the fourth hypothesis or $\mathrm{H} 4$ that Islamic work ethics positively affect the innovation Capability. It is also in line with research conducted by Kumar \& Rose (2010) [4].

The most influenced variable are employee job satisfaction and employee innovation capability, while organizational commitment and turnover intention are not really influenced by the IWE. It is probably the thing that most influences organizational commitment and intentions out of other factors. Such as compensation and benefits, performance appraisal, and other factors. Then a suggestion for academics, researchers to make a better study related to the variables in this study. It is important to do in order to know the reality of employees in shariahbased companies, whether they are comfortable working in sharia companies or not. Therefore, it is necessary to improve research related to this topic.

The implications of this research can be used by Human Resource Management in sharia and non-sharia companies. For companies that have embedded the values of work in Islam can improve the rules whether it is well implemented by the employees or not and can also evaluate the improvement of work ethics in the company. The results of the study prove that Islamic work ethics improve job satisfaction, organizational commitment, and employee innovation ability. Islamic work ethics also reduces the intention of employees out of the company. 


\section{References}

[1] D. A. Yousef, "Islamic work ethic - A moderator between organizational commitment and job satisfaction in a cross-cultural context," Pers. Rev., vol. 30, no. 2, pp. 152-169, 2001. [2] D. A. Yousef, "The Islamic work ethic as a mediator of the relationship between locus of control, role conflict and role ambiguity - A study in an Islamic country setting," J. Manag. Psychol., vol. 15, no. 4, pp. 283-298, 2000.

[3] H. B. J. Jones, "The Protestant Ethic: Weber s Model and the Empirical Literature," Hum. Relations, vol. 50, no. 7, pp. 757-778, 1997.

[4] N. Kumar and R. C. Rose, "Examining the link between Islamic work ethic and innovation capability," J. Manag. Dev., vol. 29, no. 1, pp. 79-93, 2010.

[5] A. J. Ali, “The Islamic Work Ethic in Arabia,” J. Psychol., vol. 126, no. 5, pp. 507$519,1992$.

[6] S. A. Abuznaid, "Business ethics in Islam: the glaring gap in practice," Int. J. Islam. Middle East. Financ. Manag., vol. 2, no. 4, pp. 278-288, 2009.

[7] F. Luthans, Organizational Behaviour, 11th editi. New York: Mc Graw-Hill, 2006.

[8] S. P. Robbins, Organizational Behavior, 10th editi. New Jersey: Pearson Education, Inc., 2005.

[9] A. J. Dubinsky and S. W. Hartley, "A path-analytic study of a model of salesperson performance," Sci. J. Acad. Mark., vol. 14, no. 1, pp. 36-46, 1986.

[10] D. P. Bozeman and P. L. Perrewé, "The effect of item content overlap on Organizational Commitment Questionnaire-turnover cognitions relationships," J. Appl. Psychol., vol. 86, no. 1, pp. 161-173, 2001.

[11] R. L. Mathis and J. H. Jackson, Manajemen Sumber Daya Manusia. Jakarta: Salemba Empat, 2002.

[12] P. W. Hom and W. R. Griffeth, "Structural equations modeling test of a turnover theory: Cross-sectional and longitudinal analyses," J. Appl. Psychol., vol. 76, no. 3, p. 350, 1991.

[13] R. Luna-Arocas and J. Camps, "A model of high performance work practices and turnover intentions," Pers. Rev., vol. 37, no. 1, pp. 26-46, 2008.

[14] H. Lee and B. Choi, "Knowledge Management Enablers, Processes, and Organizational Performance: An Integrative View and Empirical Examination,” J. Manag. Inf. Syst., vol. 20, no. 1, pp. 179-228, 2003.

[15] N. Malhotra, Marketing Research, 6th editio. United States of America: Prentice Hall, 2010.

[16] W. Rokhman, "The Effect of Islamic Work Ethics on Work Outcomes," Electron. J. Bus. Ethics Organ. Stud., vol. 15, no. 1, 2010.

[17] D. R. Cooper, P. S. Schindler, and J. Sun, Business research methods, Vol. 9. New York: McGraw-Hill Irwin, 2006.

[18] J. F. Hair, W. C. Black, B. J. Babin, R. E. Anderson, and R. L. Tatham, Multivariate data analysis, 6th ed. New Jersey: Pearson, 2006.

[19] R. P. Bagozzi and Y. Yi, "On the evaluation of structural equation models," J. Acad. Mark. Sci., vol. 16, no. 1, pp. 74-94, 1988.

[20] C. Fornell and D. F. Larcker., "Evaluating structural equation models with unobservable variables and measurement error," J. Mark. Res., vol. 18, no. 1, pp. 39-50, 1981.

[21] putti, J.M, Aryee, S. and Ling, T.K. (1989) Work values and organizational commitment: a study in the Asian context,Human Relations, Vol. 42, pp. 275-288. 